\title{
Hydrogeological Modelling for the Development of Raised Bog Conservation and Restoration Projects
}

\author{
Hidroǵeoloǵiskā modelēšana augsto purvu \\ saglabāšanas un atjaunošanas projektu izstrādei
}

\author{
Oḷggerts Aleksāns ${ }^{1}$, Aivars Spalviṇš ${ }^{2}$, Kaspars Krauklis $^{3}$, Juris Pētersons ${ }^{4}$ \\ ${ }^{1-3}$ Rīgas Tehniskā universitāte, Latvija, ${ }^{4}$ Biedrība "Baltijas krasti”, Latvija
}

\begin{abstract}
Kopsavilkums - Hidroğeologiskā modelēšana veikta $L I F E$ projekta "LIFE Restore - Degradēto purvu apsaimniekošana un ilgtspējīga izmantošana Latvijā" (projekta Nr. LIFE14 CCM/ LV/001103) ietvaros. Viens no svarīgiem priekšnosacījumiem sekmīgai degradēto purva teritoriju atjaunošanai ir stabilizēts hidrologiskais režīms. Pasaules praksē ir zināmi daudzi degradēto purvu atjaunošanas paṇēmieni, un lielākā daḷa no tiem ir saistīti ar hidroloǵiskā režīma izmainīšanu, stabilizēšanu vai atjaunošanu. Ĺoti populāra ir melioratīvo sistēmu pārbūve, dambēšana vai likvidēšana aizberot, reljefa planēšana un terašu veidošana, kā arī daudzi citi pasākumi. Lielākoties tie ir vērsti uz purva nosusināšanas ietekmes mazināšanu ar nolūku nodrošināt labvēlīgu hidroloğisko vidi purva veg̀etācijas atjaunošanai. Hidrog̉eologiskā modelēšana ir svarīgs instruments, kas būtiski atvieglo degradēto purvu hidroloğiskā un hidrogeoloğiskā režīma atjaunošanas un stabilizēšanas projektu izstrādi. Izmantoti Latvijas hidroğeoloğiskā modela LAMO4 dati. Modelis izveidots, īstenojot Valsts pētniecības programmu "EVIDEnT".
\end{abstract}

Atslēgas vārdi - Degradēts purvs, hidroğeologiskais modelis, pazemes ūdeṇu režīms, purva veǵetācija, ūdens līmeṇa stabilizēšana.

\section{IEVADS}

Hidroǵeoloǵiskā modelēšana realizēta Laugas purva teritorijas saglabāšanas un atjaunošanas projekta NATURA 2000 izstrādei. Laugas purvā, blakus aizsargājamajai dabas teritorijai, pašlaik notiek saimnieciska darbība - kūdras ieguve un dzērvenuu audzēšana, kas apdraud dabiskā purva ekosistēmu. Lai izstrādātu racionālu teritorijas saglabāšanas un tās hidrolog̣iskā režīma stabilizēšanas pasākumu kompleksu, tika veikta hidroǵeoloǵiskā modelēšana, kuras mērķis bija noteikt galvenos faktorus, kas var nelabvēlīgi ietekmēt purva dabiskos procesus.

Svarīgākais no faktoriem hidrolog̣iskā režīma stabilizēšanā ir purva veǵetācijai nepieciešamā ūdens līmeņa dziḷuma nodrošināšana - respektīvi, tas nedrīkst būt par dziḷu un nedrīkst arī atrasties uzpludinājuma veidā zemes virspusē. Velkot analogijas ar novērojumiem, kas veikti citos dabiskos augstā tipa purvos Latvijā, optimālais gruntsūdens līmenis purva biotopu augšanai ir $0,2-0,3$ metri no zemes virsmas. Kā rāda gruntsūdens līmeņa monitoringa novērojumi vairākos augstajos purvos Latvijā, šāds līmenis neskartā, dabiskā purvā saglabājas lielāko gada daḷu. Tomēr atsevišksos gados, parasti vasaras otrajā pusē, sausuma periodos iespējama ūdens līmeṇa pazemināšanās zem $0,5 \mathrm{~m}$ atzīmes un pat vairāk [1], [2].
Purva veǵetācijai tā jau ir bīstama robeža, jo akrotelma ${ }^{1}$ slāna biezums vairumā purvu nepārsniedz šos 0,5 metrus. Tomēr, kā rāda pieredze, nevienā no purviem šāda līmeņa pazemināšanās 2-3 mēnešu garumā nav izraisījusi purva augu segas virskārtas izžūšanu vai bojā eju.

Pretstatā dabiskajām ūdens līmen,a svārstībām purvā, kurām lielākoties ir sezonāls raksturs, antropogēnās ietekmes izraisītās ūdens līmeņa izmaiņas ir ilglaicīgas, un bieži vien to sekas ir neatgriezeniskas, ar nosacījumu, ka purva hidrologiiskā režīma saglabāšanas pasākumi netiek veikti savlaicīgi.

Laugas purva saglabāšanas un atjaunošanas projekta izstrādes ietvaros tika izveidots Laugas purva apgabala hidroǵeoloǵiskais modelis, ar kura palīdzību aprēķināti pazemes ūdens līmen,i un to plūsmas, kā arī pētīts meliorācijas grāvju ūdens režīms un to ietekme uz purva neskarto daḷu.

\section{PĒTĪJUMA OBJEKTA VISPĀRĪGS RAKSTUROJUMS}

Laugas purvs atrodas $2 \mathrm{~km}$ attālumā uz ziemeḷiemziemeḷaustrumiem no apdz̄ivotas vietas Bīriņi un apmēram $4,5 \mathrm{~km}$ uz dienvidrietumiem no apdzīvotas vietas Lēdurga, blakus valsts reǵionālajam autocel̦am Ragana-Limbaži (P9), kas savieno Krimuldas novada centru Raganu pie autoceḷa A3 ar Limbažiem. Administratīvi Laugas purva teritorija dalēji pieder Krimuldas novada Lēdurgas pagastam (austrumu daḷa) un daḷeji Limbažu novada Vidrižu pagastam (rietumu daḷa). Pētījuma objekta novietojums kartē skatāms 1. attēlā.

Ģeomorfoloǵiski teritorija atrodas uz robežas starp Piejūras zemieni un Idumejas augstieni, Metsepoles līdzenuma dienvidu daļā, uz austrumiem no Bīriņu vaļ̧̧̣a. Metsepoles līdzenuma reljefa virsmu veido subglaciālā reljefa formas, kuras līdzenuma dậa pārveidotas lokālo pieledāja baseinu un Baltijas ledus ezera krasta procesu rezultātā [3]. Vidējais teritorijas reljefa augstums ir 40-60 m vjl. [4].

Pētījumu teritorija sevī iekḷauj dabas liegumu "Laugas purvs" un tā dienvidaustrumu malai piegulošos kūdras ieguves laukus, kā arī dzērveņu audzēšanas teritoriju (1. att.). Īpaši aizsargājama dabas teritorija - Natura 2000 teritorija, dabas liegums Laugas purvs - dibināts 1999. gadā īpaši aizsargājamo putnu sugu un purva biotopu aizsardzībai. Dabas lieguma platîba ir 740 ha, un tā nav apdzīvota. Liegumā

\footnotetext{
${ }^{1}$ Akrotelms ir augšējais kūdras slānis purva ekosistēmā, kur koncentrējas biolog̣iski aktīvie procesi un notiek gruntsūdens līmeṇa svārstības.
} 
ieklauta centrālā daḷa no dabiskā Laugas purva, kura kopējā platība sasniedz 1876 ha [4].

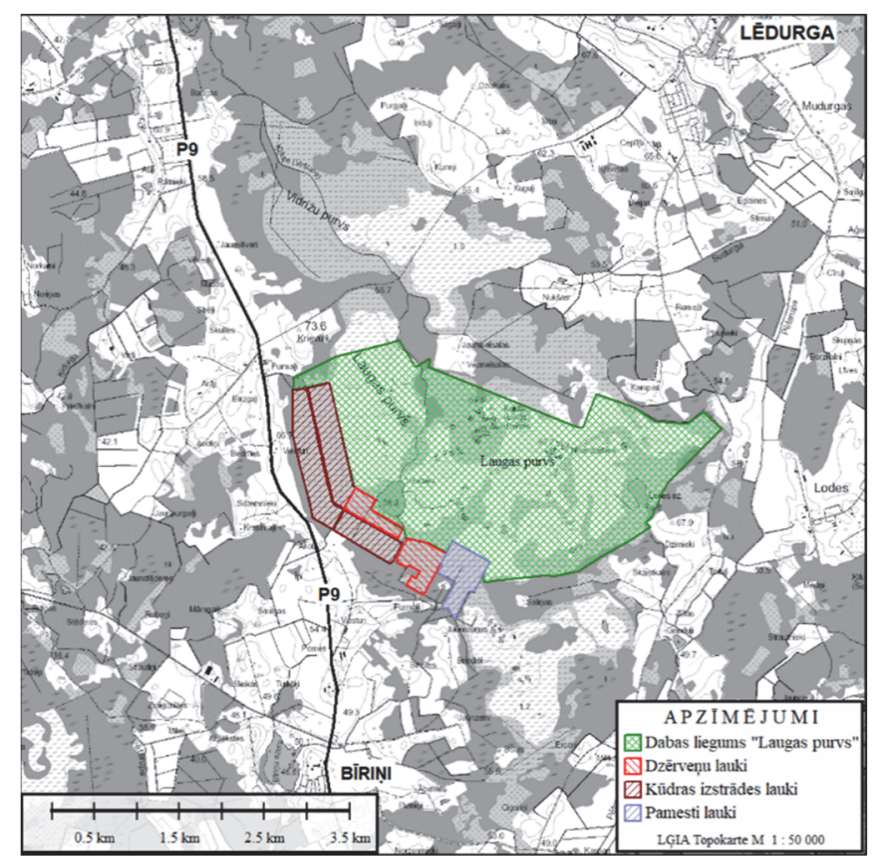

1. att. Laugas purva novietojums topogrāfiskajā kartē.

Pētījumu teritorija atrodas Vidzemes Centrālās augstienes un no tās uz ziemeliiem esošās teritorijas klimatiskajā rajonā, kas raksturojas kā viens no vismitrākajiem un aukstākajiem rajoniem Latvijāa, ko nedaudz mīkstina tuvā Baltijas jūras Rīgas līča ietekme. Gada vidējā reǵistrētā gaisa temperatūra pētījuma objekta rajonā 30 gadu laika periodā, no 1961. gada līdz 1990. gadam, bija 5,6 ${ }^{\circ} \mathrm{C}^{2}$. Vidējais atmosfēras nokrišnu daudzums, kas tiešā veidā ietekmē pētījuma teritorijas hidroloǵiskos apstākḷus, pēdējo 55 gadu laika periodā (1961.2016. gads) veidoja $763 \mathrm{~mm}$ gadā [5].

Laugas purva teritorijā atrodas divi lielāki ezeri - Višezers un Lodes ezers -, kā arī daudz mazo ezeriņu, kas koncentrējas galvenokārt Laugas purva centrālajā daḷā. No austrumu puses 10,5 ha lielajā Višezerā ieplūst purva upe Viršupe (lejtecē tiek saukta par Ķ̄̄̌supi), kas ziemeḷos izplūst no ezera un tālāk tek pa Metsepoles līdzenumu un Piejūras zemieni, bet pie Saulkrastiem ietek Baltijas jūrā.

Būtisku lomu pētîjumu teritorijas hidrologiskā režīma regulācijā ieṇem šeit esošie meliorācijas grāvji, kuri savāc un drenē virszemes ūdeņus, tādējādi ietekmējot gan paša purva hidroloǵiskos apstākḷus, gan arī ūdens līmeni Višezerā. Mazākā mērā iepriekš minētais attiecas uz Lodes ezeru, jo meliorācijas sistēmas ietekmē to mazāk.

\section{TERITORIJAS HIDROGEEOLOG̣ISKAIS RAKSTUROJUMS}

Pētījumu teritorijas pirmskvartāra ǵeoloǵisko griezumu veido apmēram 900 metrus bieza paleozoja nogulumiežu slāņkopa, kuras pamatnē ieguḷ proterozoja sistēmas kristāliskais pamatklintājs $\left(\mathrm{m}_{\gamma} \mathrm{PR}_{1} c r\right)$. Virs kristāliskā pamatklintāja sagụ kembrija $\left(\mathrm{\epsilon}_{1-2} c r\right)$, ordovika $\left(\mathrm{O}_{1-2}\right)$ un silūra $(\mathrm{S} l n-w)$ iežu komplekss, kuru diskordanti ar stratigrāfisko pārtraukumu pārklāj devona nogulumiežu slāņkopa.

\footnotetext{
${ }^{2}$ http://www2.meteo.lv/klimatariks/
}

Devona perioda nogulumieži $\left(D_{1-3}\right)$ ir pārstāvēti pilnā griezumā - sākot ar apakšdevona Kemeru $\left(\mathrm{D}_{1} \mathrm{~km}\right)$ svītu un beidzot ar augšdevona Gaujas horizonta nogulumiežiem ( $\left.\mathrm{D}_{3} g j\right)$. Jaunāki nogulumieži par $\mathrm{D}_{3} g j$ pētījumu teritorijā ir noārdīti vēlāk sekojošajā kontinentālā apledojuma laikā ledāju un to kušanas ūdeņu darbības rezultātā. Kopējais devona kompleksa nogulumiežu biezums mainās no $370 \mathrm{~m} \mathrm{līdz}$ $500 \mathrm{~m}$.

G̦eoloǵiskā griezuma augšējo daḷu veido kvartāra nogulumu sega, kuras biezums pētījumu teritorijā nav pastāvīgs un atkarībā no reljefa artikulācijas variē robežās no 30 metriem un vairāk dabas lieguma "Laugas purvs" rietumu malā līdz 15 metriem un mazāk austrumos, Pēterupes ielejā. Zem kvartāra segas pagul augšdevona Gaujas horizonta nogulumieži.

Kvartāra slāņkopu veido galvenokārt Latvijas svītas glacigēnie nogulumi - morēnas smilšmāls un mālsmilts, izņemot tās platības, kur tie zemes virspusē pārklāti ar dažādas g’enēzes un sastāva holocēna un augšējā pleistocēna veidojumiem.

Kvartāra segas morēnā vai zem tās var būt arī smilts un grants nogulumi, kuri sastopami kā mainīga biezuma saraustītas un deformētas starpkārtas vai arī kā līdz 2-5 metru un vairāk biezi slāṇi, kas iestarpināti morēnas masīvā. Turklāt minētie nogulumi veido atsevišķus paugurus, grēdas, masīvus vai šo formu kodolus un pamatnes. Smilts, aleirītiskas smilts un grants nogulumi var pārklāt arī atsevišķu starppauguru un ielejveidīgo pazeminājumu nogāzes vai aizpildīt to gultnes [6].

Teritorijā ir plaši izplatîti virs morēnas sagulošie Latvijas svītas fluvioglaciālie nogulumi, kuri pētījumu rajonā sastopami atsevišḳu laukumu veidā. Holocēna perioda nogulumi, kas veidojās Zemes ǵeoloǵiskās vēstures pēdējos 10 tūkst. gados, pētījumu teritorijā ir pārstāvēti atsevišķu upju ielejās alūvija veidā un purvos kā kūdra un sapropelis.

Îpaši plaši ir izplatīti purva nogulumi, kuru biezums dažādās vietās ir atšķirīgs, bet maksimālais konstatēts Laugas purvā, kur izteikti dominē augstais purvs, un ierobežotās teritorijās arī pārejas un zemais purvs. Purva nogulumus pārsvarā veido kūdra, bet atsevišksos gadījumos ir konstatētas arī sapropeḷa starpkārtas.

No hidroǵeoloǵiskā viedokḷa galvenā loma plānoto atjaunošanas pasākumu realizācijai projekta teritorijā un modeḷa izstrādei ir kvartāra ūdens horizontu kompleksam, kas sevī ietver purva nogulumus, kā arī zem kvartāra segas pagulošajiem Gaujas, Burtnieku un Arukilas ūdens horizontiem. Dziḷāk atrodas reǵionālais, 60-126 m biezais ūdeni vāji caurlaidīgo iežu sprostslānis, kas atdala virs tā esošo aktīvās ūdens apmaiņas zonu no dziḷāk iegulošajiem pasīvās ūdens apmaiṇas zonas horizontiem.

Purva nogulumu ūdens horizonts ir izplatīts lielākajā projekta teritorijas daḷā un ir galvenais pētījuma objekts. Laugas purvs ir viens no lielākajiem šajā rajonā, ar līdz pat $8 \mathrm{~m}$ biezu kūdras slāni [4]. Laugas purva nogulumu ūdens horizonts sagul uz Latvijas svītas glacigēnajiem smilšmāla un mālsmilts nogulumiem. Purva ūdens horizonta līmeņi praktiski vienmēr ir augstāki par pagulošajiem horizontiem, un tāpēc purva ūdeņu filtrācija ir vērsta no augšas uz leju - uz zemāk esošo horizontu. Tomēr ir arī lokāli izṇēmumi, kur purvu zemākajās vietās vai to nomalēs pagulošā horizonta ūdens līmenis ir augstāks par gruntsūdens līmeni purva nogulumos. Šādas vietas ir Laugas purva periferiālajā zonā, kā 
arī izstrādātajos kūdras laukos Laugas purva dienvidudienvidrietumu daḷā (1. att.).

Reǵionālā gruntsūdens plūsma lielākajā Laugas purva daḷā ir vērsta rietumu vai ziemeļrietumu virzienā, un tikai salīdzinoši nelielā teritorijā Višezera rajonā virszemes plūsma notiek dienvidu-dienvidaustrumu virzienā. Savukārt Laugas purva austrumu dal̦ā, Lodes ezera sateces baseinā, virszemes ùdeņu plūsmā dominē austrumu virziens. Minēto ilustrē virszemes noteces modelēšanas rezultāti, kas skatāmi 2. attēlā.

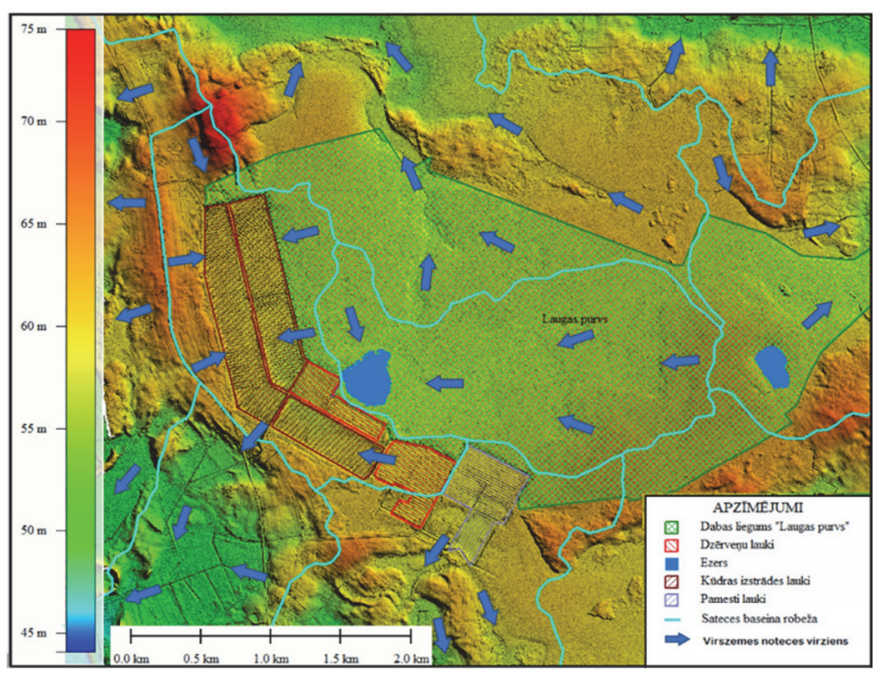

2. att. Gruntsūdens sateces baseinu un plūsmas virzienu karte.

Saskaņā ar hidroǵeoloǵiskajiem pētījumiem citos augstajos purvos Latvijā [7], purva nogulumu filtrācijas koeficients parasti svārstās starp $0,02-0,04 \mathrm{~m} / \mathrm{d}$. Līdz ar to šo nogulumu ūdens atdeve ir neliela, un filtrācija kūdras slānī notiek lēni, galvenokārt pateicoties hidrostatiskajam spiedienam. Tieši tāpēc izteikti lielākā purva daḷā gruntsūdens horizonta ūdeņi notek ar virszemes plūsmu caur akrotelma slāni, atslogojoties dabiskajās ūdenstecēs vai meliorācijas grāvjos.

Būtiskāku, bet ne noteicošu, lomu kvartāra nogulumu ūdens apmaiņā ieņem pētāmajā teritorijā sastopamie morēnas masīva iekšienē vai tā pamatnē izvietotie vairākus metrus biezie nogulumi no dažādgraudainas smilts-grants un oḷu piejaukumu. Šie iekšmorēnas slāņi jeb "lēcas" var saturēt arī spiedienūdeņus, kas var būt hidrauliski saistīti ar purva nogulumiem un tādējādi sekmēt to ūdens krājumu papildināšanos.

\section{HIDROĢEOLOG̣ISKĀ MODELĒŠANA}

Hidroǵeoloǵiskā modelēšana realizēta Rīgas Tehniskās universitātes Datorzinātnes un informācijas tehnoloğijas fakultātes Vides modelēšanas centrā (VMC). Pētījums veikts, izmantojot licencētu programmatūru "Groundwater vistas 6" (GV) [8] un SURFER12 programmu [9] grafisko materiālu noformēšanai. Izmantoti VMC izveidotā Latvijas hidroǵeolog̣iskā modeḷa LAMO4 dati [10] un pārskata [11] materiāli.

Hidroǵeoloǵisko modeli veido astoņi slāņi [11] (I. tabula); no tiem pirmais un astotais kalpo kā robežnoteikums ar fiksētu ùdens līmeni. Šo slāṇu pieṇemtais biezums modelī ir tikai $0,02 \mathrm{~m}$, tie neapraksta reālus ǵeologiskos slāṇus dabā, bet ir nepieciešami kā virtuāls elements modelī tā robežnosacījumu definēšanai. Arī formālais 2. sprostslānis nepieciešams tikai meliorācijas grāvju pareizai piesaistei reljefam.
I TABULA

LAUGAS PURVA APGABALA HM VERTIKĀLĀ SHEMATIZĀCIJA UN MODELĪ IZMANTOTIE HIDROG̣EOLOG̣ISKIE PARAMETRI

\begin{tabular}{|c|c|c|c|c|c|c|}
\hline \begin{tabular}{|c|}
$\mathrm{HM}$ \\
slāņa \\
Nr. \\
\end{tabular} & $*$ & $\begin{array}{c}\text { Slāņa } \\
\text { nosaukums }\end{array}$ & $\begin{array}{l}\text { Slāņa } \\
\text { kods }\end{array}$ & $\begin{array}{c}\text { Filtrācijas } \\
\text { koeficients, } \\
\text { m/dnn }\end{array}$ & \begin{tabular}{|c|} 
Biezums, \\
$\mathrm{m}$
\end{tabular} & Piezīmes \\
\hline 1. & & $\begin{array}{l}\text { Reljefa } \\
\text { virsma }\end{array}$ & rel & 10,00000 & 0,02 & Robežnoteikums \\
\hline 2. & $=$ & $\begin{array}{l}\text { Aerācijas } \\
\text { zona }\end{array}$ & aer & 0,10000 & 0,02 & \\
\hline 3. & = & $\begin{array}{c}\text { Purva } \\
\text { augša un } \\
\text { morēna }\end{array}$ & B3, gQ & $\begin{array}{l}0,50000 \\
\text { un } \\
0,00140\end{array}$ & 0,70 & $k_{z} / k_{x y}=0,1$ \\
\hline 4. & 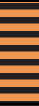 & $\begin{array}{c}\text { Purva vidus } \\
\text { un morēna }\end{array}$ & B2, gQ & $\begin{array}{l}0,01000 \\
\text { un } \\
0,00140\end{array}$ & & \\
\hline 5. & $=$ & $\begin{array}{c}\text { Purva } \\
\text { apakša un } \\
\text { morēna }\end{array}$ & B1, gQ & $\begin{array}{c}0,00100 \\
\text { un } \\
0,00140\end{array}$ & & \\
\hline 6. & & Morēna & $\mathrm{gQ}$ & 0,00140 & & $k_{z} / k_{x y}=0,3$ \\
\hline 7. & = & $\begin{array}{c}\text { Apakšējais } \\
\text { Gaujas } \\
\text { sprostslānis }\end{array}$ & D3gj1z & 0,00028 & & \\
\hline 8. & & $\begin{array}{c}\text { Apakšējais } \\
\text { Gaujas } \\
\text { horizonts }\end{array}$ & D3gj1 & 10,00000 & 0,02 & Robežnoteikums \\
\hline
\end{tabular}

Hidroǵeologiskā modeḷa režǵa plaknes aproksimācijas solis ir 4 metri. Kā augšējais robežnoteikums modelī izmantots digitālais reljefa modelis, kurš ir aproksimēts un pielāgots modeḷa prasībām (3. A att.). Purva malas līnija modelī atdala purvu no mālsmiltīm (melnā līnija 3. A attēlā), kurām, līdzīgi kā Latvijas hidroǵeologiskajam modelim LAMO4, filtrācijas koeficients ir noteikts $k=0,0014 \mathrm{~m} / \mathrm{d}$.

Kvartāra morēnas nogulumus gQ modelē 6. slānis, kura apakšējā virsma ṇemta no LAMO4, un morēnas nogulumu filtrācijas koeficients pieņemts $k=0,0014 \mathrm{~m} / \mathrm{d}$ [12]. Purva nogulumu (kūdras) izplatības areāla robežās par gQ augšējo virsmu HM izmanto $53 \mathrm{~m}$ vjl, kas modelī nodrošina mainīgu purva nogulumu biezumu (3. B att.). Model̦a dienvid-rietumu stūrī šīs virsmas augstums samazinās zemāka reljefa dēḷ.

Sprostslāni G3gj1z modelē 7. slānis. Tā biezums mainās no dažiem metriem ziemeḷu-ziemeḷrietumu daḷā līdz $15 \mathrm{~m}$ un vairāk modeḷa dienvidaustrumu stūrī. Pieņemtais filtrācijas koeficients Gaujas sprostslānim $k=0,00028 \mathrm{~m} / \mathrm{d}$; izmantoti LAMO4 dati [10].

Kā robežnoteikums 1. slān̄ un HM augšas ǵeometriskā virsma izmantots digitālais reljefs, kuram veikta digitālā filtrēšana, lai to nogludinātu. Robežnoteikums 8. slān̄̄ horizontam D3gj1 ņemts no LAMO4 [10]. Model̦a aktīvo daļu veido sprostslāṇi, tāpēc modeḷa vertikālās sānu virsmas ir ūdens necaurlaidīgas un tām nav izmantoti ūdens līmeṇu robežnoteikumi (izņemot 1 . un 8 . slāni).

Modelētie ūdens līmeņi purva apakšā B1 un morēnā gQ skatāmi attiecīgi 4. A un 4. B attēlā.

Hidrogrāfiskā tīkla elementi "pieslēgti” 3. slānim B3. Ķ̄īupe, strauts un grāvis modelēti kā $G V$ robežnoteikums "River", bet ezers kā $G V$ robežnoteikums "General Head Boundary". Upes, strauta un grāvja pazemes ūdens pieteces grafiki iegūti ar GV rīku "Mass Balance" režīmā "BC Flow Accreation Curve". 
A

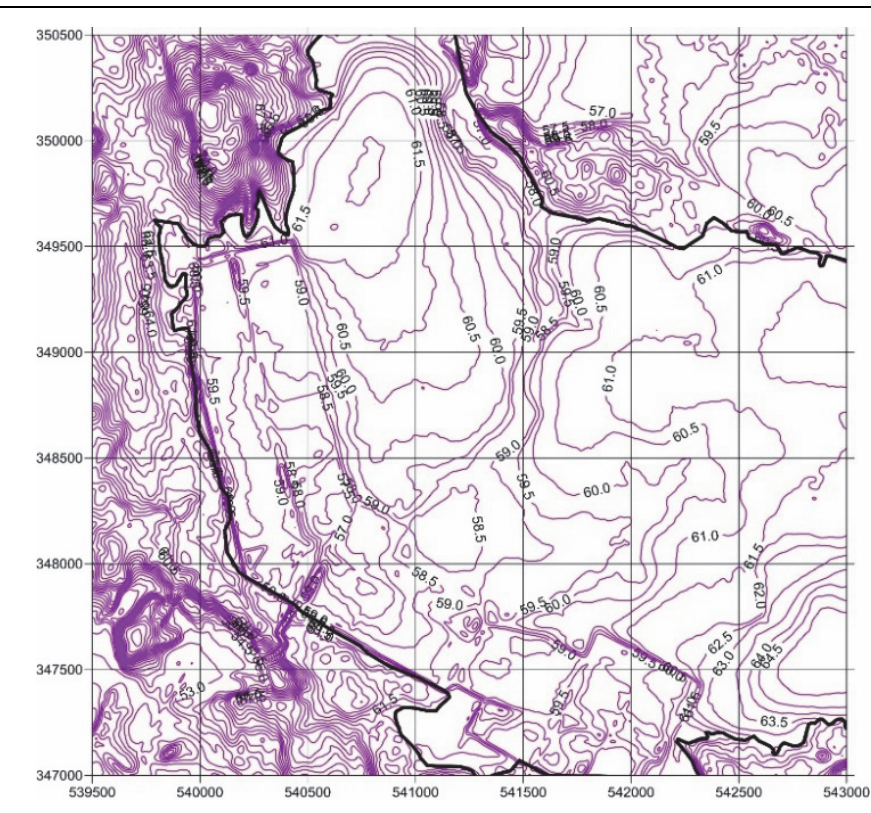

B
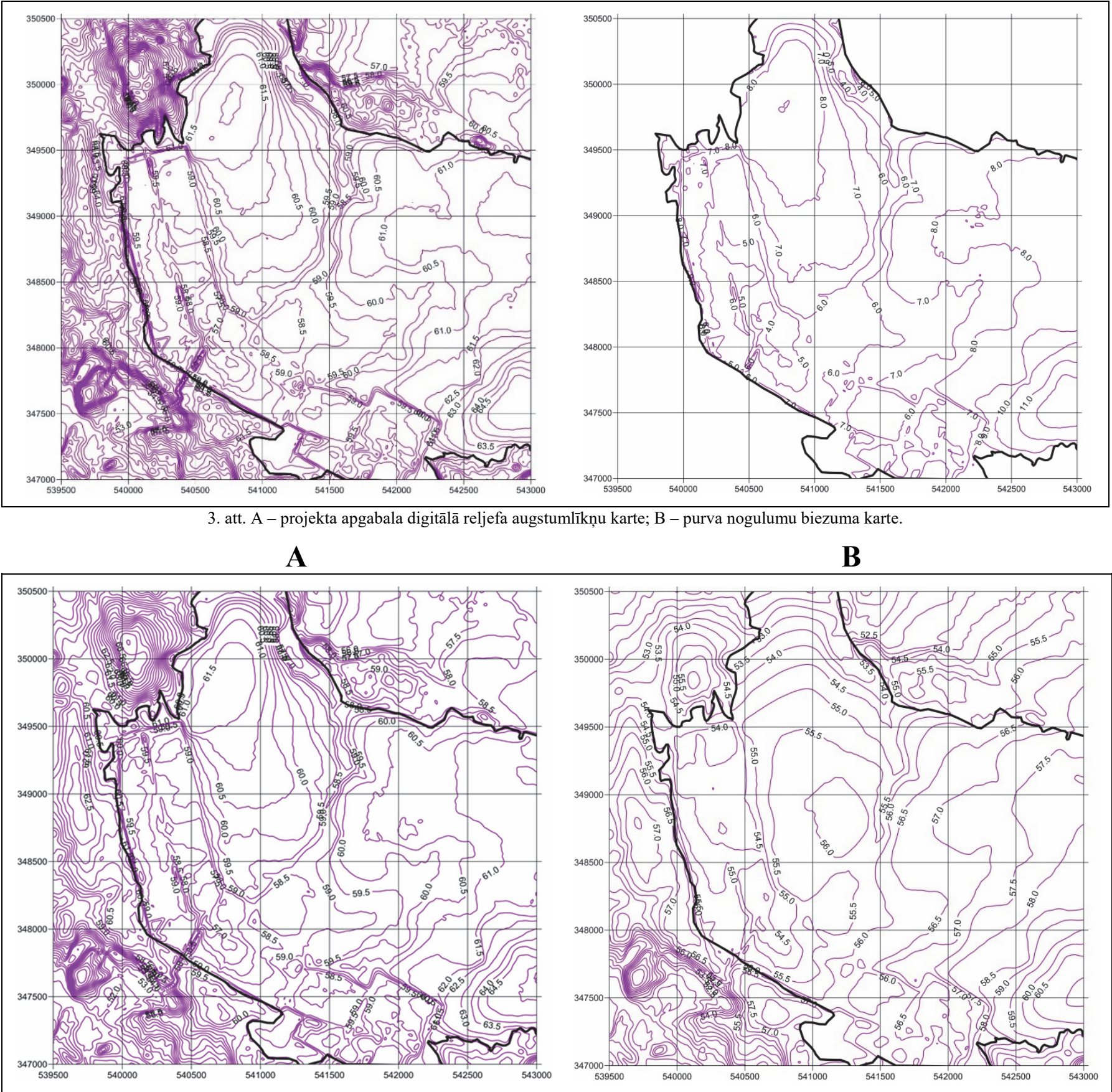

B

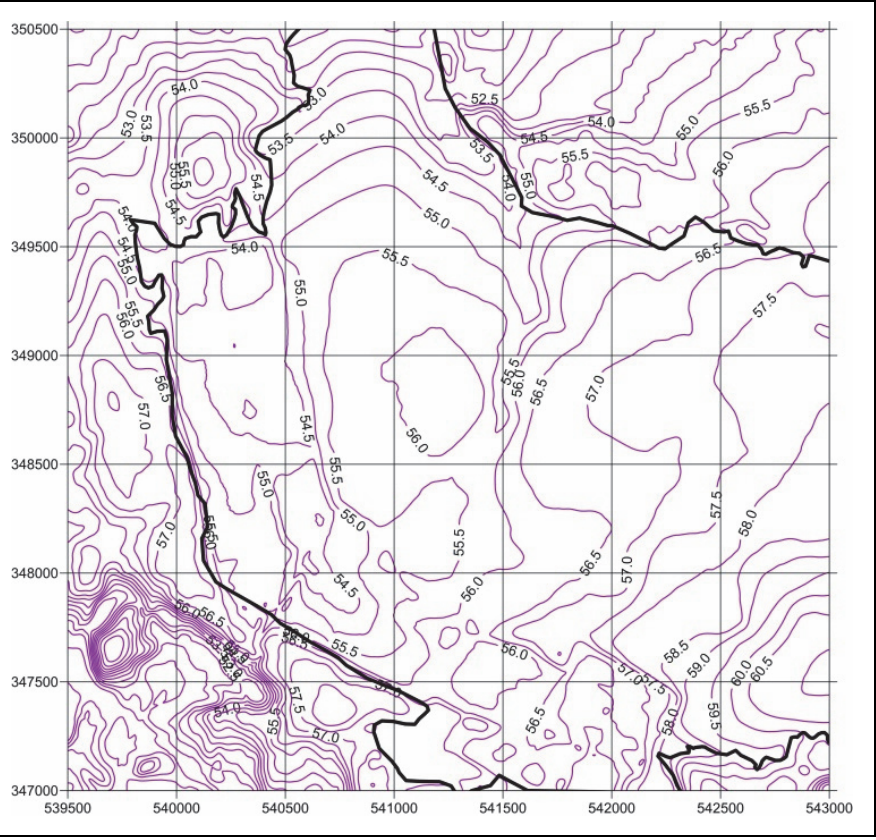

4. att. A - pazemes ūdens līmenis B1 slānī, m vjl.; B - pazemes ūdens līmenis gQ slānī, m vjl.

Saskaņā ar modelēšanas rezultātiem [11], Viršupē/Ķ̄ǐšupē no purva ieplūst apmēram $180 \mathrm{~m}^{3} / \mathrm{d}$ gruntsūdens. Upes posmā ārpus purva, kurā tā plūst pa mālsmilts nogulumiem, gruntsūdens atslodze upē nenotiek, vai arī tā ir l’oti niecīga un ar to var nerēkināties. Purva upē, kura ietek Višezera austrumu malā (skat. 6. A att.), no purva augšējā, labi filtrējošā slāņa upē ieplūst apmēram $13 \mathrm{~m}^{3} / \mathrm{d}$ ūdens.

Salīdzinoši liels ūdens daudzums no purva dabiskās daḷas aizplūst rietumu-dienvidrietumu virzienā - kūdras izstrādes laukus ierobežojošajā kontūrgrāvīi-317 m³/d.

Hidroǵeolog̣iskās modelēšanas rezultāti liecina (skat. II. tabulu), ka no ezera caur tā pamatni apmēram $70 \mathrm{~m}^{3} / \mathrm{d}$ ūdens iefiltrējas dziḷākajos pazemes horizontos. Neliela ūdens dạ̣a no ezera aizplūst gruntsūdens veidā caur tā krasta zonu.

Hidrogeologiskās modelēšanas rezultāts liecina, ka Višezera pastāvēšanu un tā hidrologiisko režīmu galvenokārt nodrošina tas ūdens daudzums, kas ezerā nonāk no purva caur augšejo, labi filtrējošo nesadalījušās kūdras (t. sk. akrotelma) slāni, kā arī virszemes notece ceḷā.

Izmantojot modelēšanas programmā paredzēto iespēju noteikt vertikālās plūsmas ātrumu $V_{z} \mathrm{~m} / \mathrm{d}$, var aprēķināt infiltrācijas plūsmu sadalījumu $V_{z} \times 365000, \mathrm{~mm} /$ gadā, visiem modeḷa slāṇiem. Tā ir svarīga informācija par ūdens apmaiņu gan starp atsevišķiem horizontiem, gan arī, 
konkrētajā gadījumā - starp modelī virtuāli nodalītajiem purva nogulumu slāniiem B3, B2 un B1.

Modelē̌̌anas rezultāti uzrāda [11], ka visintensīvākā infiltrācija notiek purva nogulumu augšējā (B3) slānī (skat. I. tabulu). Modelētā gruntsūdens horizonta (B3) ūdens krājumu papildināšanās no atmosfēras nokrišņiem to vertikālās filtrācijas rezultātā, $\mathrm{mm} /$ gadā, projekta un tai piegulošajās teritorijās skatāma 5. attēla kartē.

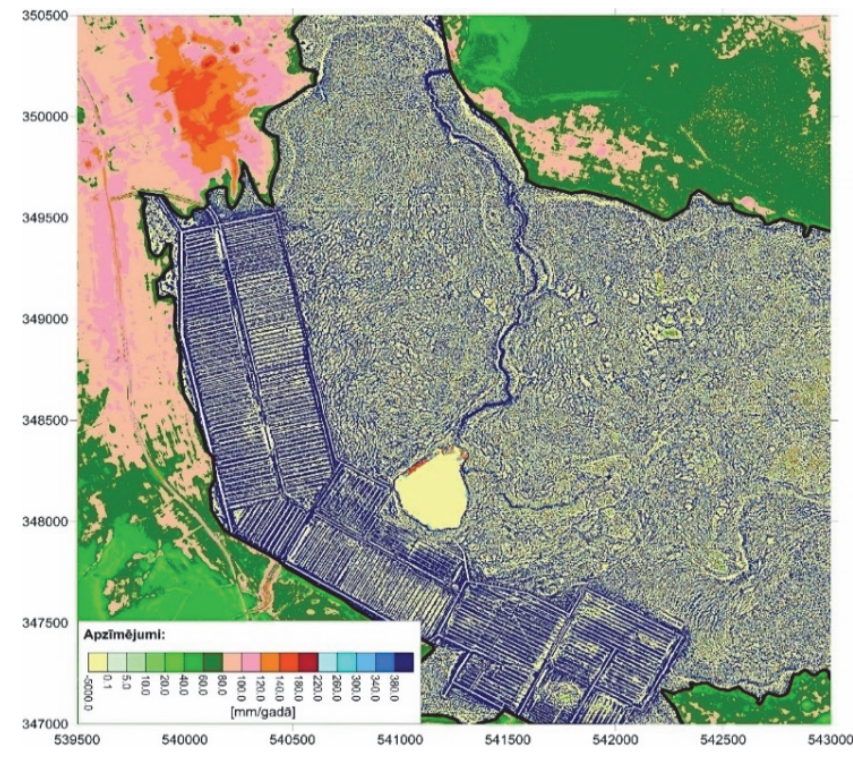

5. att. Modelētā purva nogulumu slāṇa B3 ūdens krājumu papildināšanās ar atmosfēras nokrišņiem to vertikālās infiltrācijas rezultātā, mm/gadā.

No š̄is kartes redzams, ka visā purva masīvā notiek intensīva atmosfēras nokrišṇu infiltrācija, kas pārsniedz 300$350 \mathrm{~mm} /$ gadā, un tas ir gandrīz puse no tās vidējās gada A

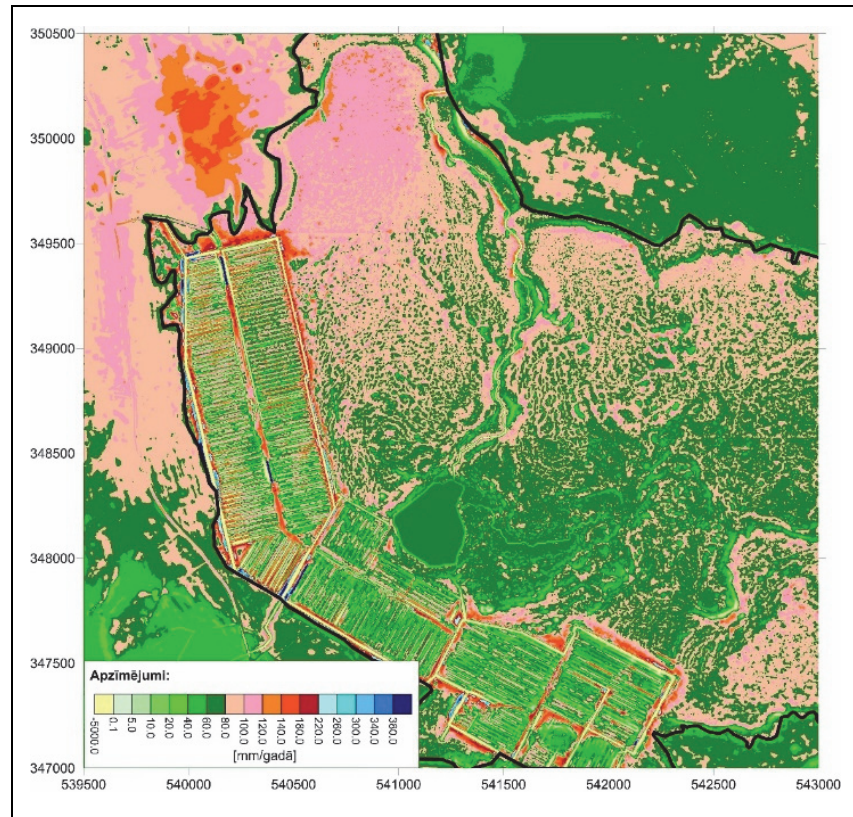

nokrišnu summas $(763 \mathrm{~mm})$. Salīdzinājumam: purvam piegulošajā teritorijā atmosfēras nokrišņu infiltrācijas rādītāji modelētajam B3 slānim ir daudzreiz mazāki un parasti nepārsniedz 100-150 mm/gadā (skat. karti 5. attēlā).

Vienlaicīgi jāatzīmēe, ka purva dabīgajā daḷā, paralēli nokrišnu infiltrācijai, tāpat vērojama iztvaikošana, tajā skaitā arī no Višezera ūdens virsmas (5. attēla kartē dzeltenā krāsa), kas nav tipiski purvam piegulošajai teritorijai. Uz ūdens iztvaikošanu no purva augšējā slāņa B3 norāda 5. attēlā skatāmais raksturīgais kartes mozaīkas raksturs.

Divās nākamajās kartēs 6. attēlā dota purva ūdens krājumu papildināšanās mm/gadā vertikālās filtrācijas rezultātā no augstāk iegulošā (pārklājošā) slāṇa: A - modelētajam purva nogulumu slānim B2; B - purva nogulumu slānim B1. No šīm kartēm redzams, ka vertikālās ūdens pārteces apjoms ar dziḷumu samazinās, kas arī ir logiski, jo, palielinoties dziḷumam, pieaug kūdras blīvums un samazinās tās filtrācijas koeficients.

Purva dabīgajā daḷā B2 slānī caurmērā nonāk vairs tikai 40-60 mm/gadā (skat. 6. A attēlu). Virzienā uz purva perifēriju, it īpaši ziemeḷu-ziemeḷrietumu virzienā , infiltrācijas rādītājs B2 slān̄ palielinās līdz 80-100 mm gadā. Ti un nedaudz mazāk - dienvidaustrumu virzienā, infiltrācijas e ir nogabali, kuru ietvaros zemāk esošais kūdras slānis B1 saṇem ūdeni infilttrācijas ceḷā no augšējā B2 nogulumu slāṇa. Šeit notiek intensīiāka vertikālā ūdens pārtece virzienā no augšas uz leju salīdzinājumā ar purva centrālo daḷu.

Kopsavilkums par pazemes ūdeņu bilances elementu aprēķinu visam Laugas purva model̦a laukumam, kas iegūts ar modelēšanas programmā iebūvēto rīku "Mass balance", dots II. tabulā.

6. att. Modelētā purva ūdens krājumu papildināšanās vertikālās filtrācijas rezultātā no augstā iegulošā slāṇa, mm/gadā:

A - purva nogulumu slānim B2; B - purva nogulumu slānim B1.

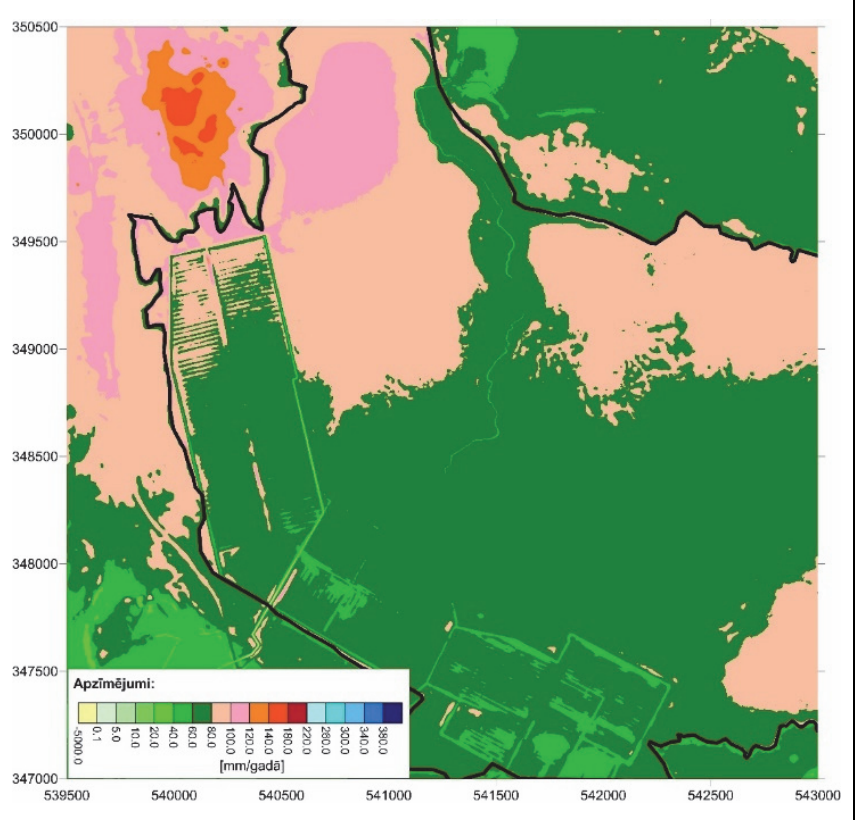


II TABULA

PAZEMES ŪDEN̦U BILANCES ELEMENTU APRĒK়INS LAUGAS PURVA MODEḶA TERITORIJAI

\begin{tabular}{|c|c|c|c|c|c|c|c|c|c|c|}
\hline \multirow{2}{*}{$\begin{array}{l}\text { Slāņa } \\
\text { kods }\end{array}$} & \multicolumn{3}{|c|}{ Slāņa augša } & \multicolumn{3}{|c|}{ Slāņa apakša } & \multirow{2}{*}{$\frac{\text { Kopā }}{4+7}$} & \multirow[t]{2}{*}{ Robeža } & \multirow{2}{*}{$\begin{array}{l}\text { Upes, } \\
\text { grāvji }\end{array}$} & \multirow[t]{2}{*}{ Ezeri } \\
\hline & Ieplūde & Izplūde & $2+3$ & Ieplūde & Izplūde & $5+6$ & & & & \\
\hline 1 & 2 & 3 & 4 & 5 & 6 & 7 & 8 & 9 & 10 & 11 \\
\hline aer & 12687,9 & $-10066,7$ & 2621,2 & 9973,3 & $-12594,3$ & $-2621,0$ & 0,2 & $-0,2$ & 0,0 & 0,0 \\
\hline B3 & 12594,3 & $-9973,3$ & 2165,0 & 782,1 & $-2962,6$ & $-2180,5$ & 440,5 & $-0,4$ & $-510,0$ & 69,9 \\
\hline B2 & 2962,6 & $-782,1$ & 2180,5 & 3,5 & $-2183,9$ & $-2180,4$ & 0,1 & $-0,1$ & 0,0 & 0,0 \\
\hline B1 & 2183,9 & $-3,5$ & 2180,4 & 0,0 & $-2180,2$ & $-2180,2$ & 0,2 & $-0,2$ & 0,0 & $\overline{0,0}$ \\
\hline $\mathrm{gQ}$ & 2180,2 & 0,0 & 2180,2 & 0,9 & 0,0 & $-2179,3$ & 0,9 & $-0,9$ & 0,0 & 0,0 \\
\hline D3gj1z & 2179,3 & 0,0 & 2179,3 & 0,0 & $-2179,3$ & $-2179,3$ & 0,0 & 0,0 & 0,0 & 0,0 \\
\hline Modelis & 12687,9 & $-10066,7$ & 2621,2 & 0,0 & $-2179,3$ & $-2179,3$ & 441,9 & $-1,8$ & $-510,0$ & 69,9 \\
\hline
\end{tabular}

II. tabulā redzams, ka purva virskārtā (modelī definēta kā aerācijas zona), kas varētu atbilst akrotelma slānim dabā, notiek intensīva ūdens ieplūde $\left(12688 \mathrm{~m}^{3} / \mathrm{d}\right)$ un izplūde $\left(-10067 \mathrm{~m}^{3} / \mathrm{d}\right)$. Interesanti atzīmēt, ka ūdens pārtece caur modela slāṇu pamatni praktiski visos līmeņos ir vienāda $\sim 2180 \mathrm{~m}^{3} / \mathrm{d}$. Tas ir ūdens daudzums, kas nonāk augšējā devona Gaujas ūdens horizontā un papildina tā pazemes ūdens krājumus. Savukārt horizontālā plūsma (8. kolonna II. tabulā) visos horizontos (izņemot augšējo B3 slāni) praktiski nenotiek un ir vienāda ar nulli.

\section{SECINĀJUMI}

Modelēšanas rezultāti apstiprina faktu, ka dabas lieguma "Laugas purvs" augstā purva veǵetācijas saglabāšanai viens no svarīgākajiem priekšnosacījumiem ir stabilizēts hidrologiiskais režīms. Purva veǵetācijai lielākos draudus rada nevis nokrišṇu iztrūkums vasarā, bet gan tā centrālajā daḷā esošā Višezera ūdens līmeṇa izmainas. Tieši Višezers ir dabas lieguma centrālais elements, kas nodrošina ūdens līmeņa stabilitāti Laugas purva centrālajā dạ̦ā apmēram 319 ha platībā.

Laugas purva hidroǵeoloǵiskais modelis izveidots uz Latvijas hidroǵeoloǵiskā modẹa LAMO4 bāzes. LAMO4 izstrādāts, īstenojot Valsts pētniecības programmu "EVIDEnT".

\section{LITERATŪRAS SARAKSTS}

[1] O. Aleksāns, "Hidroloǵiskie un geolog̣iskie pêtījumi Ziemeḷu purvu dabas liegumā," Mitrāji Life+ Project. Rīga, 2015 [Online]. Available: http://www.mitraji.lv/wpcontent/uploads $/ 2015 / 02 /$ Hidrolo\%C4\%A3iskie-un$\% \mathrm{C} 4 \% \mathrm{~A} 3$ eolo\%C4\%A3iskie-p\%C4\%93t\%C4\%ABjumiZieme $\% \mathrm{C} 4 \% \mathrm{BCu}$-purvu-dabas-liegum $\% \mathrm{C} 4 \% 81$.pdf

[2] O. Aleksāns, Hidrogeologiskajam novērtējumam kūdras ieguvei atradnē „Nidas purvs” Dienvidkurzemes mežsaimniecības Nīcas meža iecirkṇa teritorijā Rucavas novada Rucavas pagastā, sēj. Pārskats, Rīga: DGE Latvia SIA, 2014.

[3] K. Lamsters, Fenoskandijas ledus vairoga Zemgales loba subglaciālā reljefa sistēms un dinamika, promocijas darba kopsavilkums. Rīga: Latvijas Universitāte, 2015 [Online]. Available: https://www.geo.lu.lv/fileadmin/user_upload/lu_portal/projekti/gzzf/zin as/Prom-kops_Lamsters_Kristaps_final.pdf

[4] Eko forums, Dabas lieguma "Laugas purvs Dabas aizsardzības plāns laika posmam no 2017. lìdz 2029. gadam, red. G. Freimane. Rīga: biedrïba "Baltijas krasti", 2016/2017 [Online]. Available: https:// www.daba.gov.lv/upload/File/DAPi apstiprin/DL Laugas purvs 17.pdf

[5] O. Aleksāns, Latvijas nokrišnnu karte laika periodam no 19̄61. līdz 2016. gadam. Rīga: Nepublicēti dati, 2017.

[6] V. Zelčs, "Limbaži uval moraine area," Pleistocene Stratigraphy, Ice Marginal Formations and Deglaciation of the Baltic States. Tallinn: Estonian Academy of Sciences, 1993.
[7] V. Drikis un J. Prols, Atskaite par hidrogeologiskajiem darbiem Kemeru un Jaunķemeru rajonā savstarpējās ietekmes izpētei (iepriekšêjā stadija) starp sērūdeņradi saturošajiem ūdeñiem un saldūdeņiem ar mērki noskaidrot to krājumu pārvērtēšanas nepieciešamību, sēj. 1. Skrunda: Latvijas ǵeolog̣ijas pārvalde, 1985.

[8] Environmental Simulations, Inc., Groundwater Vistas version 6. Guide to Using, 2011.

[9] Golden Software, Inc, SURFER. User's Guide, 2011.

[10] A. Spalviňš, Pārskats "Latvijas hidrogeologiskā modela LAMO pilnveidošanas starprezultāti." Rīga: VMC, 30. lpp., 2015 [Online]. Available: http://www.emc.rtu.lv/VPP/ATSK_LVGMC_2015 teksts.pdf

[11] A. Spalviņ̌š, Pārskats Laugas purva apgabala hidrogeologiskā modelēšana. Rīga: Rīgas Tehniskā universitāte, 15. lpp. 2017.

[12] B. S. Maslov, Gidrologija torfjanyh bolot, t. Uchebnoe posobie, Tomsk: Tomskij gosudarstvennyj universitet, 2008.

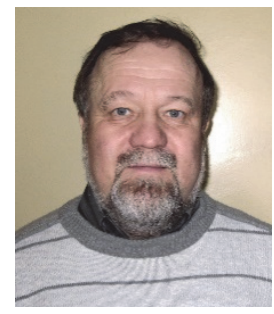

Olgerts Aleksāns was born in Latvia. In 1979, he graduated from Vilnius State University as a Hydrogeologist \& Engineering Geologist. In 2011, O. Aleksans received the Doctor's degree in Geology. Since 2011, he is a researcher at the Environment Modelling Centre of RTU.

E-mail: oal@dge.lv;

olgerts.aleksans@gmail.com

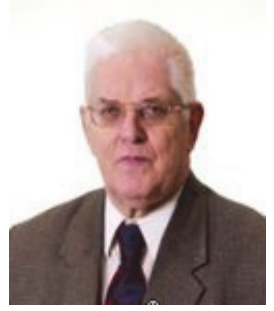

Aivars Spalvin̄š was born in Latvia. In 1963, he graduated from the Riga Polytechnical Institute (since 1990 - Riga Technical University) as a Computer Engineer. A. Spalvinus is the Head of the Environment Modelling Centre of RTU. His research interests include computer modelling of groundwater flows and migration of contaminants. E-mail: Aivars.Spalvins@rtu.lv

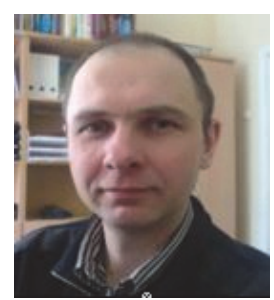

Kaspars Krauklis received the Master's degree in Computer Systems from the Riga Technical University in 2007 and the Certificate in Teaching of Engineering Sciences from the Institute of Humanities of RTU in 2005. He is a researcher at the Environment Modelling Centre of RTU.

E-mail: kasparskrauklis@gmail.com

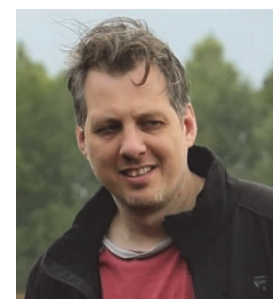

Juris Pētersons. Mg oec., Biedrība "Baltijas krasti". More than 15 years' experience in the field of environmental protection, development and improvement of environmental infrastructure to minimise the human impact with the aim to increase the spread of the natural environment. Activities include different projects financed from the EU financial instruments and the State Budget. E-mail:www.juris@gmail.com 
Hydrogeological Modelling for the Development of Raised Bog Conservation and Restoration Projects

Olgerts Aleksāns ${ }^{1}$, Aivars Spalviņš̌², Kaspars Krauklis ${ }^{3}$, Juris Pētersons ${ }^{4}$

${ }^{1-3}$ Riga Technical University, Latvia, ${ }^{4}$ Association Baltic Coasts, Latvia

Hydrogeological modelling was carried out within the framework of the LIFE project "LIFE Restore - Management and sustainable use of degraded bogs in Latvia" (project No. LIFE14 CCM / LV / 001103).

A stabilizing hydrological regime is one of the important preconditions for successful restoration of degraded bogs. Many practices of regeneration of degraded bogs are known in the world, and most of them relate to the exchange, stabilization or recovery of hydrological regime. It is very common to rebuild, block or eliminate land drainage systems, land elevation planning and building of terraces, as well as many other methods. Most of these techniques are aimed at mitigating the impact of drainage of the bog in order to provide a favourable hydrological environment for the restoration of raised bogs vegetation.

Hydrogeological modelling is an important tool that greatly facilitates the development of hydrological regime restoration and stabilization projects for degraded high bogs.

Hydrogeological modelling was carried out applying the data provided by hydrogeological model of Latvia LAMO4. Development of the model was supported by the Latvian State Research Program EVIDEnT.

Keywords - hydrogeological model, raised bog, groundwater, water level stabilization, raised bog vegetation, conservation and restoration. 